\title{
The Bretan Case: a Paradox between Value and Promotion
}

\author{
LOREDANA IAŢEŞEN \\ “George Enescu” National University of Arts Iasi \\ ROMANIA*
}

\begin{abstract}
On the occasion of the 50th anniversary of the passing of the Transylvanian musician Nicolae Bretan (1887-1968), known during the interwar period due to his complex field of activity (interpreter, director, conductor, composer), we consider it necessary to elaborate a study that is critical for several reasons. Starting with the dilemmatic comments existent in the current bibliography, we propose, on the one hand, to systematize the information regarding the reception of his personality in the context of the age in which he lived and worked, and on the other hand, to outline the premises that generated the appearance of controversial writings, but especially to question their effects on the deformed stylistic perception of the musician at national and international level. We consider that this is one of the ways in which the "phenomenon of Bretan's rebirth" can be objectively reevaluated, appreciating the existence and real contributions of a minor musician, who, although endowed with talent, could not be in the same compositional direction that included national models (George Enescu, Mihail Jora, Paul Constantinescu), are comparable to those in the universal space of the first half of the 20th century.
\end{abstract}

Keywords: interwar creator, critical reception, epigonism, minor musician.

\section{Introduction}

In the perception of meanings of the dilemmatic figures of history, the delimitation of the reality-fiction ratio seems increasingly difficult for the contemporary critic. Preoccupied by the reconstitution of past personalities, the contemporary critic has the opportunity to uncover incomplete or shrouded myths, based on contradictory theories, which may generate other controversies while documenting a possible research.

\subsection{Argument}

In order to argue these ideas, we went through the essay What is an Author? from the volume Language, Counter - Memory, Practice, in which the researcher Michael Foucault construes the author's image, from the perspective of the literary critic of the past century's last decades: "If we are accustomed to presenting the author as a genius, as a perpetual effervescence of inventions, it is because in reality, we make the author work exactly in the opposite way"

\footnotetext{
*iatesenloredana@yahoo.com
} 
(Foucault, 1980, p. 308). By transposing Michael Foucault's opinion from the literary and musical point of view, we understand that the tendency to exaggerate certain features of a biographical or compositional nature was present in the monographic research of the second half of the 20th century, mitigating the image of a creator. The unfavorable consequences of such a phenomenon were not delayed and materialized in today's reception, deforming the figures of some artists, due to the subjective systematizations of historical, stylistic, cultural information and moreover, as a result of contradictions with dramatic significance in hierarchy values.

\subsection{Scope}

In the following research, we propose to re-evaluate the personality of the Transylvanian interwar musician Nicolae Bretan from a dual perspective: on one hand, the perception of the creator in the first half of the 20th century, where he manifested himself in a polyvalent way, and on the other hand, his reconsideration in contemporaneity. To this end, we shall emphasize the idea that the promotion of the composer in the present has positive but especially negative consequences, through overestimating the value of his stylistic music in an abusive advertising campaign, which determines the configuration of a distorted image of the artist subject to our attention.

\section{Microportrait}

The 50th anniversary of the passing of the musician Nicolae Bretan ${ }^{1}$ is an opportunity to reflect on his personality with multiple preoccupations: lied, opera and oratorio interpreter, composer, conductor, director, poet, librettist and translator. From the standpoint of his singing activity, ${ }^{2}$ he accomplished himself on the lyrical scenes of Bratislava, Oradea and Cluj, by playing multiple roles ${ }^{3}$

\footnotetext{
${ }^{1}$ Nicolae Bretan was born on March 25, 1887 (in Năsăud) and died on December 1, 1968 (in Cluj-Napoca). 'His musical studies began under the guidance of the composer Iacob Mureșianu (Solfège theory, harmony) in his hometown and continued at the Conservatory of Cluj (19061908) with Farkas Ödön (singing, composition) and Gyémánt (violin). He continued his studies at the Akademie für Musik und darstellende Kunst of Vienna (1908-1909) with Gustav Geiringer (canto) and Julius Meixner (declamation), as well as at the Academy of Music of Budapest (1909-1912) with Siklós Albert (theory), Szerémi Gusztáv (violin), Sik József (canto), Molnár Géza (music history). In parallel, he attended courses at the Faculty of Letters of Cluj and graduated in 1910 '(Cosma, 1989, p. 207).

2 'He debuted as a baritone (1913) on the stage of theatres in Bratislava (1913-1914) and Oradea (1914-1916), continuing his career as singer and stage director at the Hungarian Theatre of Cluj (1917-1922), first baritone (1922-1940), stage director (1922-1940, 1946-1948) and director (1944-1945) at the Romanian Opera of Cluj and stage director at the Hungarian State Theatre and the Hungarian Opera House (1940-1944)' (Cosma, 1989, p. 207).

3 'Iago (Othello, Verdi); Amonastro (Aida, Verdi); Mephisto (Faust, Gounod), Escamillo (Carmen, Bizet); Scarpia (Tosca Puccini); Telramund (Lohengrin, Wagner); Eugene Onegin
} 
from the Italian, French and German romantic repertoire. As a director, he staged works signed by different composers ${ }^{4}$ of national and universal lyrical creation at the Romanian Opera and the Hungarian Theatre in Cluj.

The literary talent and the full knowledge of the linguistic peculiarities of the Romanian, Hungarian and German cultures are qualities that made it easier for Nicolae Bretan to approach the miniature or scenic genres. He composed many lieder (220) based on the lyrics of representative poets from his native space (M. Eminescu, O. Goga, G. Coşbuc, T. Arghezi, V. Eftimiu) or of international ones (H. Heine, N. Lenau, Petőfi Sándor, Vörösmarty Mihály, Ady Endre) and six operas: [Luceafărul] The Morning Star (1921); [Revolta lui Golem] The Golem's Revolt (1924); [Eroii de la Rovine] Heroes from Rovine (1934); Horia (1937) Arald (1939); [Stranie seară de Sedar] The Weird Evening of Sedar (1952). He composed instrumental pieces for piano, violin, psalms, a requiem and less known works.

From the brief enumeration of the main directions of his musical activity, we notice the inclination of the artist Nicolae Bretan to the vocal field, his passion for the art of singing and his cultural opening reflected on several levels: interpretative, directorial and compositional.

\section{Possible influences when choosing the compositional career}

While trying to understand the motives of the baritone N. Bretan to embrace the compositional career, we found out surprising aspects; knowing that Professor Farkas Ödön initiated him in the mysteries of this field during his studies at the Conservatory of Cluj.

On the one hand, the lexicographer Viorel Cosma, in the preface of the lied scores, emphasized the idea that the artist was trully appreciated as an interpreter of opera roles, while on the other hand the musicologist Octavian Lazar Cosma, in his volume [Hronicul muzicii românești] A Chronicle of Romanian Music - in an enumeration of soloists who collaborated with the Orchestra of the Ministry of Public Education in Bucharest (1912-1913 season) - recalled the name of Nicolae Bretan and characterized him as 'not too bright' (Cosma Lazar, 1983, p. 142). In order to highlight the initial stylistic orientation of the creator, the same author mentioned in another publication a fragment from the correspondence of Nicolae Bretan with Gheorghe Dima dated February 16, 1907. From the same letter, we find out that the musician sent the score of the lied Sara on the Hill to his mentor of Cluj and wrote him that “...I did not send it to director Farkas from the Conservatory, because he cultivates the so-called Hungarian music (he is a hungarized Puccini), with which my

(Eugene Onegin, Tchaikovsky); Nilakantha (Lakmé, Delibes); Figaro (The Barber of Seville, Rossini)' (Cosma, 1989, p. 207).

4 'Mozart, Gluck, Wagner, Verdi, Puccini, Smetana, Bizet, Leoncavallo, Mascagni, Delibes, Donizetti, Offenbach, Brediceanu, Drăgoi, Negrea’ (Cosma, 1989, p. 207). 
German way of thinking has nothing in common.I would really like to go to Bucharest next year and become the pupil of Mr. Popovici"' (Cosma Lazăr, 1996, p. 130).

What did we notice? Although he had a broad interpretative activity, appreciated and contested in the same manner, the passion for creation followed him since the beginning of his studies at the Conservatory (1906-1907) and contributed to a great deal of self-accomplishment in his compositional career, which evolved in parallel. Unfortunately, the musician did not deepen this field technically, taking conventional style and language models from the universal creation within the first half of the nineteenth century, which determined the partial recognition of his personality in the context of the interwar generation (Sabin Drăgoi, Mihail Jora, Marțian Negrea, Paul Constantinescu and George Enescu); this through a sporadic appearance of articles in various cultural daily newspapers.

\section{Reception of the composer in the context of his time}

An important source around the reception of the musician can be found in the volume [Viața muzicală în Ardealul de după Unire] The Musical Life in Transylvania after the Great Union, which quotes the following idea from an extract of [Gazeta ilustrată] The Illustrated Gazette (1936): "Here is the first Romanian opera on the lyrical stage of Cluj, [Luceafărul] The Morning Star of Eminescu!... A breath of deep religiousness pervades the creation of Mr. Nicolae Bretan. It is a pity that he limited himself to keeping the epic frame of Eminescu's [Luceafărul] The Morning Star, without elaborating a development, a culmination and a more plastic denouement of the action, without dramatizing enough Eminescu's conception” (Gherghel, 1936, pp. 6-7).

A closer insight of the score of this work, through the analysis of a fragment from the debut of the Epilogue, reveals that music has a romantic expression. It is a feature conferred first by the pastoral sonorous introduction (paragraphs 44-45), which highlights the romantic intonations of chordophone discreetly accompanied by a harp. It follows the thematic idea (paragraphs $45 \rightarrow 47$ ), deduced from the content of the introductory musical material, with the distinction of melodic construction and writing, which reminds of the sound of a hymn. The theme is profiled as an initial diatonic exposition, evolving in the sequential treatment of discourse, suggesting the image of incarnation of the Morning Star. We notice the traditional orchestration, known from the scores of German romantic composers (Carl Maria von Weber and Ferdinand von Hiller), with the gradual accumulation of sonority in the timbral plane until reaching its peak.

\footnotetext{
${ }^{5}$ Extract from the correspondence of Nicolae Bretan with Gh. Dima, from the archives of the Chivulescu family, Brasov.
} 
TABLOUL III

(EPILOGUL)
III-es BILD

(DAS NACHSPIEL)

(Scena la fel en in Tabloul 1. Numai infáțişarea Luceafárului este vizibilă intă de la ridicarta cortinei, El are iaróși aripi ingeresti.)

(bie Bühne wie im Iten Bild, Nur ist die Gestalt des Abendsterns stehon sofort nach dem Aufgehen des Vorhanges sichtbar, er hat wieder grobe Engelflüget.)
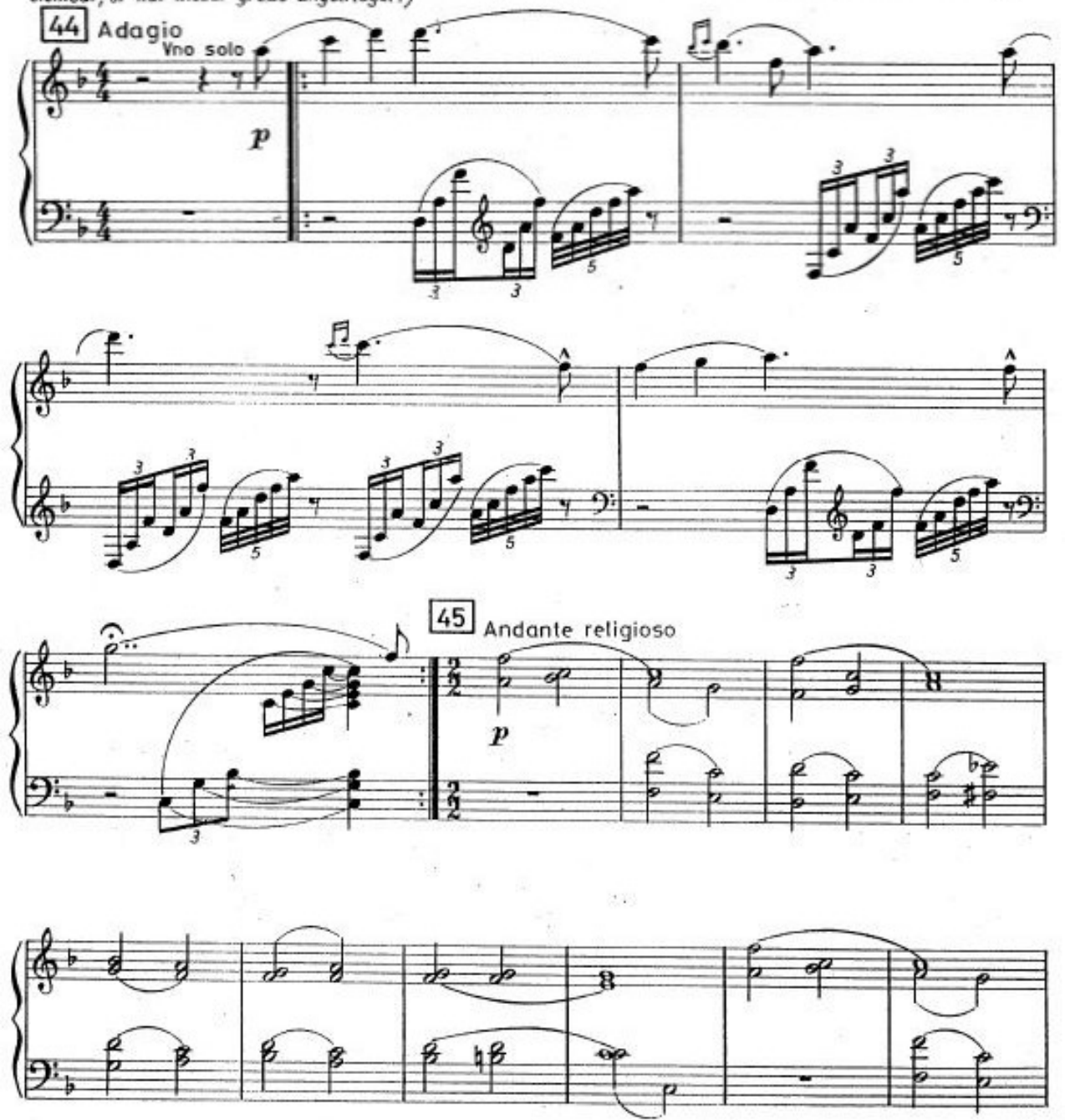

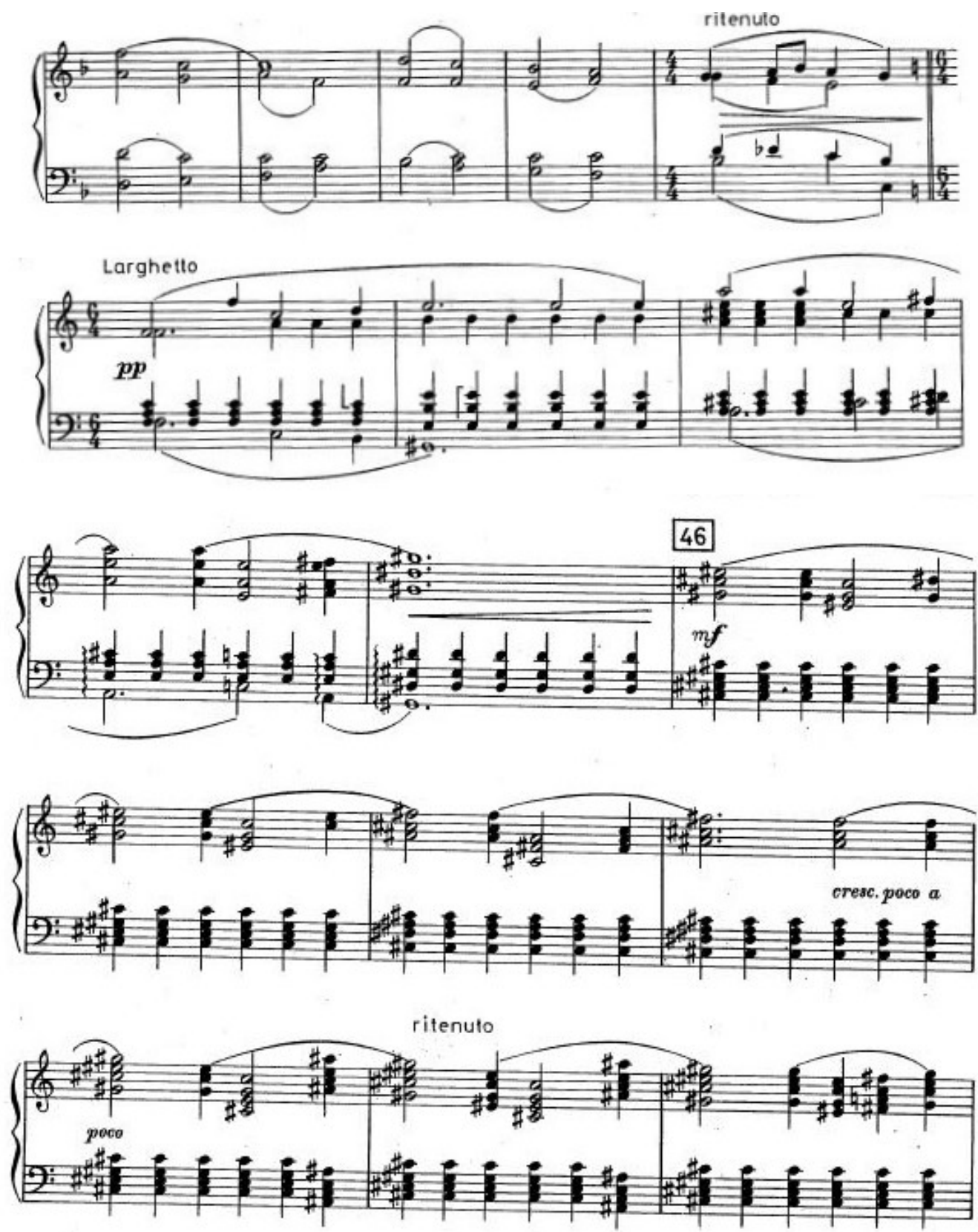

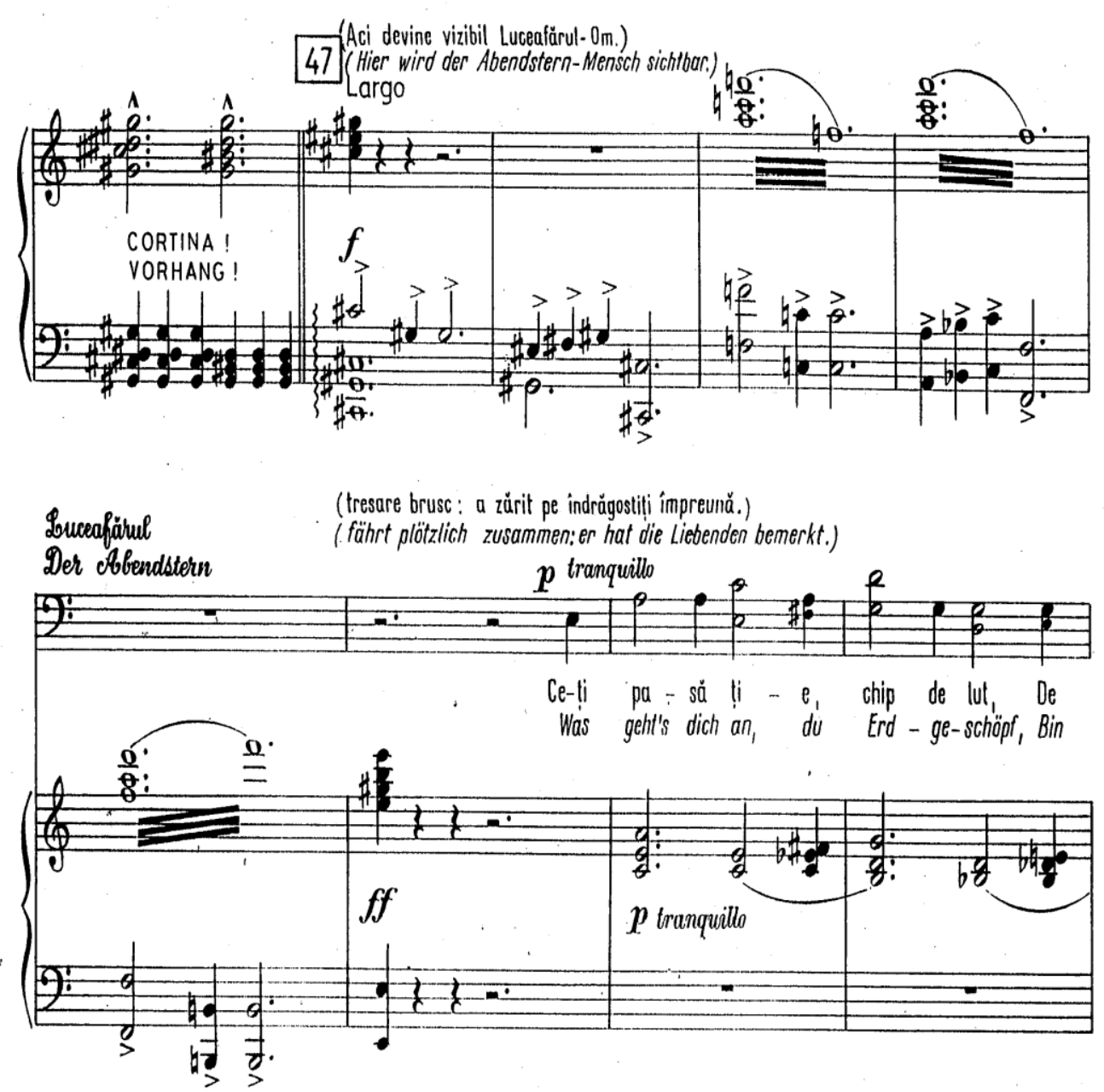

Fig. 1 Nicolae Bretan, Luceafărul [The Morning Star], Epilogue, $44 \rightarrow 47^{+8}$

Horia, another show recorded in the periodical Muzică și Poezie [Music and Poetry] (1937) by Victoria Dragoş Ursu, was perceived as an "evocation of a lyrical episode of the peasants' revolution with a music inspired by Transylvanian folklore"6 (Ursu-Dragoş, 1937, p. 32). Surprisingly, in Gazeta ilustrată [The Illustrated Gazette] (1939), we find out about the same score and specialized critical comments. “...From a musical point of view, the opera Horia should be subject to thorough review. The orchestral part should be

\footnotetext{
${ }^{6}$ In the same publication, we find another positive comment regarding the same creation just a few months later: "The Peasant Rebellion of 1784 - the love idyl of Horia's daughter and the betrayal of Huţu, were happily transposed into the dramatic music of the five paintings richly inspired from folklore. Themes of Awaken thee, Romanian were used as leitmotifs". (Miletineanu, 1937, p. 30).
} 
completely altered and deepened, in order to emphasize the scenic situations more seriously, as well as to ensure a more dramatic characterization of the melodramatic conflicts. That does not mean that we wish too bold innovations of harmony and counterpoint. The fragments of the various national hymns should be organically merged with the other musical motifs, so that their appearance does not leave the impression that they are mere intercalations" (Gherghel, 1939, p. 102).

However, the clearest perception of the musician is evidenced by the documented statements of the researcher Octavian Lazar Cosma in the volume Universul muzicii românești [The Universe of Romanian Music]. According to this source, the artist ${ }^{7}$ is mentioned in different stages of his life, in the absence of observations related to the compositional activity.

We remember that the musician Nicolae Bretan imposed himself at that time and was recognized as a creator. He was a member of the Union and most of his works were sung: [Luceafărul] The Morning Star ${ }^{8}$ (1921), [Revolta lui Golem] The Golem's Revolt ${ }^{9}$ (1924), [Eroii de la Rovine] Heroes from Rovine ${ }^{10}$ (1934) Horia ${ }^{11}$ (1937). Moreover, his scenic works were commented on in different cultural periodicals. Although he was not integrated in the context of the compositional peak of the interwar period, which is evident from the sporadic records of creative activity, the image of a composer dedicated to the lyrical theatre did not go unnoticed and, as we can see from the documents of the time, he was appreciated or criticized for his capacity of constructing diverse librettes and melodies as inspirational sources.

\footnotetext{
${ }^{7}$ In an item of the lists kept in 'File 434/1949 (State Archives, Bucharest, Archive of the Union of Composers'), we find the name of Nicolae Bretan in 'Rubric 4, the category of inactive or unknown composers' (Cosma Lazăr, 1995, p. 186). 'The Commission, gathered on May 27, 1950, rejected the request of Nicolae Bretan to become a member of the Union recently created on the structure of the Societatea Compozitorilor Români' [Society of Romanian Composers] (Cosma, O. L., 1995, p. 209). 'Rejected in the spring of 1954' (Cosma, O. L., 1995, p. 261) and readmitted in autumn, when he was granted a 700 Lei retirement from the Musical Fund of the Union' (Cosma, O. L., 1995, p. 275). 'His membership was reconfirmed in 1958' (Cosma, 1995, p. 324). 'At the 1968 General Assembly a moment of silence was held for the musicians that passed away’ (Cosma, 1995, p. 395), among whom the name of Nicolae Bretan is recorded. ${ }^{8}$ Opera in one act, with Prologue, 3 scenes and Epilogue, libretto by Nicolae Bretan, lyrics by Mihai Eminescu, premiere in Cluj on February 2, 1921, Opera Română [Romanian Opera], conductor Jean Bobescu.

${ }^{9}$ Musical drama in one act, libretto by Nicolae Bretan after the drama [Golem vrea să fie om] The Golem Wants to Be a Man, Illés Kaczér, premiere in Cluj on December 23, 1924, Hungarian Theatre, conductor Nicolae Bretan.

${ }^{10}$ Opera in an act, libretto by Nicolae Bretan after [Scrisoarea a III-a] Letter III of Eminescu, premiere in Cluj on January 24, 1935, [Opera română] Romanian Opera conductor, N. Brody.

11 Opera in 3 acts and seven scenes, libretto adapted by Bretan after the play of Ghiţă Pop, premiere in Cluj on January 24, 1937, [Opera Română] Romanian Opera, conductor Max Săveanu.
} 


\section{Promotion campaign of the composer Nicolae Bretan. Strategies and achievements}

After the artist's death in 1968, his daughter, Judit Bretan ${ }^{12}$ married the American diplomat Harry Le Bovit and has undertaken numerous actions to promote the image of the musician in our country and abroad. Since 1973, she has organized vocal miniature recitals in different centers: Braşov, Târgu Mureș, Cluj, Dej, Bucharest. In 1974, the show [Stranie seară de Sedar] The Weird Evening of Sedar ${ }^{13}$ was played for the first time in America. In 1980, the opera Horia ${ }^{14}$ was included in the repertoire of the lyrical theatre of Bucharest, while in 1982 the show Arald ${ }^{15}$ was premiered in Iași. Lied recitals dedicated exclusively to Bretan's music became more and more frequent in Romania and various cities in America: Cleveland, Ohio; Houston, New York, Washington. Gradually, his music was discovered by many performers who constantly promoted him: Dan Iordăcescu, Eugenia Moldoveanu, Valentin Teodorian, Gheorghe Crăsnaru, Ludovic Konya etc. Judit Le Bovit also worked on the publication of score books and, since 1993, with the support of the cultural foundation that she initiated in 1977 (the Nicolae Bretan Music Foundation), she contributed to the editions of the [Festivalul Concurs Nicolae Bretan] Festival Contest Nicolae Bretan within the framework of the Music Academy G. Dima. We also recall the radio broadcasts in the country (Cluj, Bucharest) and especially abroad, thanks to the involvement of Fred Calland ${ }^{16}$, producer of classical music programs (1970-1989) at the National Public Radio of the United States of America.

What followed? Although the results of the advertising campaign materialized immediately, with an ascending evolution of over two decades, the

\footnotetext{
12 Judit Bretan, daughter of Nicolae Bretan (Cluj, 1923 - Washington, 2018), was an actress in the period 1938-1947 and played different roles in Cluj, Bucharest, Budapest etc. Following her marriage to US diplomat Harry Le Bovit, she moved to Washington, U.S.A., in 1949, where she worked as a foreign language teacher, being recognized for her modern methods of teaching Latin.

${ }^{13}$ A mystery in one act based on texts - in Hungarian - from a Haggadah for voice, organ (piano) and violin, [Stranie seară de Sedar] the Weird Party of Sedar (1952) was premiered on September 8, 1974 at the Bradley Hills Presbyterian Church, in Bethesda, Maryland, U.S.A.

${ }^{14}$ Conductor of the show: Cornel Trăilescu, directed by: George Teodorescu, scenography: Hristofenia Cazacu; Horia's role interpreted by: George Crâsnaru and Nicolae Florei.

15 Show in one act (1939), libretto by Bretan after [Strigoii] The Strigas of M. Eminescu; premiere in the [Opera Română] Romanian Opera of Iași, conductor Corneliu Calistru.

${ }^{16}$ Fred Calland (1924-1999) was a filmmaker, producer and director of the Classical Music Department of the National Public Radio. In 1970 he joined the N.P.R. team. His personal collection has often served as the main source for recorded music programs. He hosted many live events, including first auditions of musical shows. In 1989, Calland withdrew from the N.P.R. team and became the main producer. After that, he worked as an occasional commentator at N.P.R. and continued to be involved for many years in the realization of his program World of Opera on WETA-FM.
} 
relationship between promotion and reception was gradually contoured. We have discovered two stages, depending on the degree of impact of Bretan's music on the interpretative field, moreover, in relation to the reception of his opposites from the perspective of general-cultural or specialized criticism.

\section{Relationship amid promotion and reception between 1969-1995. Positive consequences}

In the volume [Istoria muzicii românești] A History of Romanian Music of 1969, Petre Brâncuşi ascertained observations regarding the works of composers from the first half of the 20th century (Sabin Drăgoi [Năpasta] The Calamity, Marțian Negrea [Marin Pescarul] Marin The Fisher, Alexandru Zirra, Alexandru Lăpuşneanu, Paul Constantinescu, [O noapte furtunoasă] A Stormy Night), compared to Nicolae Bretan's scenic works ([Luceafărul] The Morning Star, [Eroii de la Rovine] Heroes of Rovine, Horia), mentioned 'for information purposes' (Brâncuși, 1969, p. 192).

A few years later, the frequency of recitals lied dedicated to lieder created by the composer provokes the options of some critics who, in the chronicles published in various cultural newspapers, add substantial stylistic comments about gender approach. For example, the lied recital by the baritone Dionisie Konya and the pianist Ferdinand Weiss, which took place in the concert hall of Bucharest Conservatory in 1973, was referred to by the authors of two articles that appeared in different publications: Grigore Constantinescu' ${ }^{17}$, 'Nicolae Bretan', in [Contemporanul] The Contemporary and Alfred Hofmann, 'Nicolae Bretan's Concert', in [România liberă] Free Romania. This is how Hofmann characterized the vocal miniature in Bretan's view: "It is a romance pervaded by a certain nobility of feeling... There are sometimes dramatic accents ([Ș-acele dulci păreri de rău] Those Sweet Remorses, [Rugăciune după război] Prayer after War). We may also observe the evolution towards a more advanced subtlety in the musical monologue ([Gazel] Ghazal on verses by Coşbuc), while the twinning with the expressiveness of Romanian folk songs gives a remarkable force to those pages ([Pe dealul Feleacului] On Feleac Hill)" (Hofmann, 1973, p. 2).

A closer approach to the romance score [Lasă-ți lumea ta uitată] Leave your World Forgotten (1921) reveals the sensual nostalgic content of Eminescu's lyrics, through a melody built with due attention to the discrete

\footnotetext{
17 "It is an ambiance of the romanticism of always, more necessary for the vitality of singing than stylized searches, from which the simple, convincing melody emerges naturally. As a keeper of the Romanian singing tradition, which differs in many of its elements from the line of lieder, Nicolae Bretan leaves to voice the liberty of soaring in elegant volutes and stopping shortly on declamatory pauses, intimately connecting the vocal chamber piece to the best romance as gender”. (Constantinescu, 1973, p. 6).
} 
emphasis of all expressive vocal resources, in correspondence with the suggestive pianistic accompaniment.

\section{Iassa-ti lumea tạ nitată Lass' die Welt uns ganz vergessen Forget your world \\ MIHAI EMINESCU}
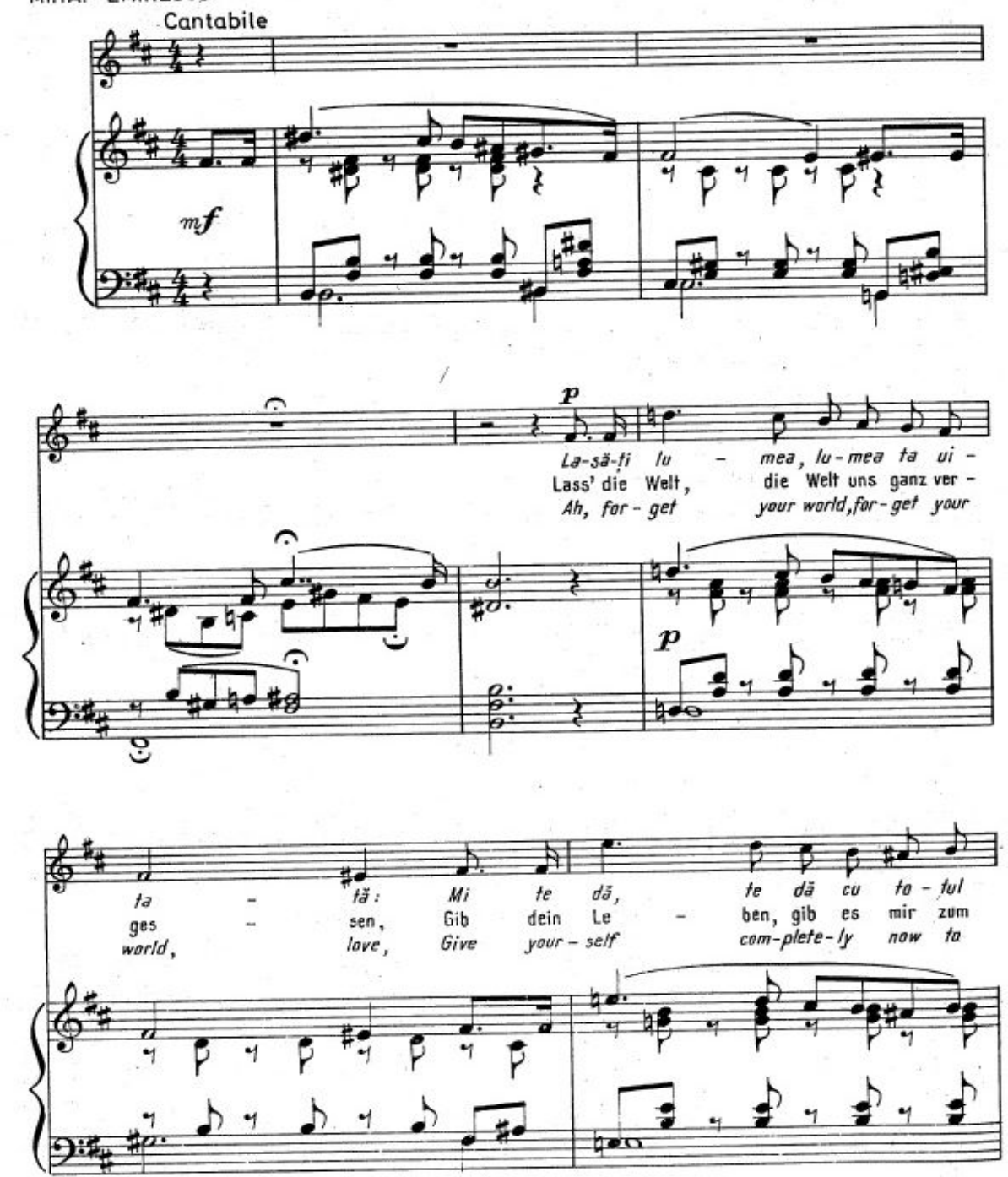

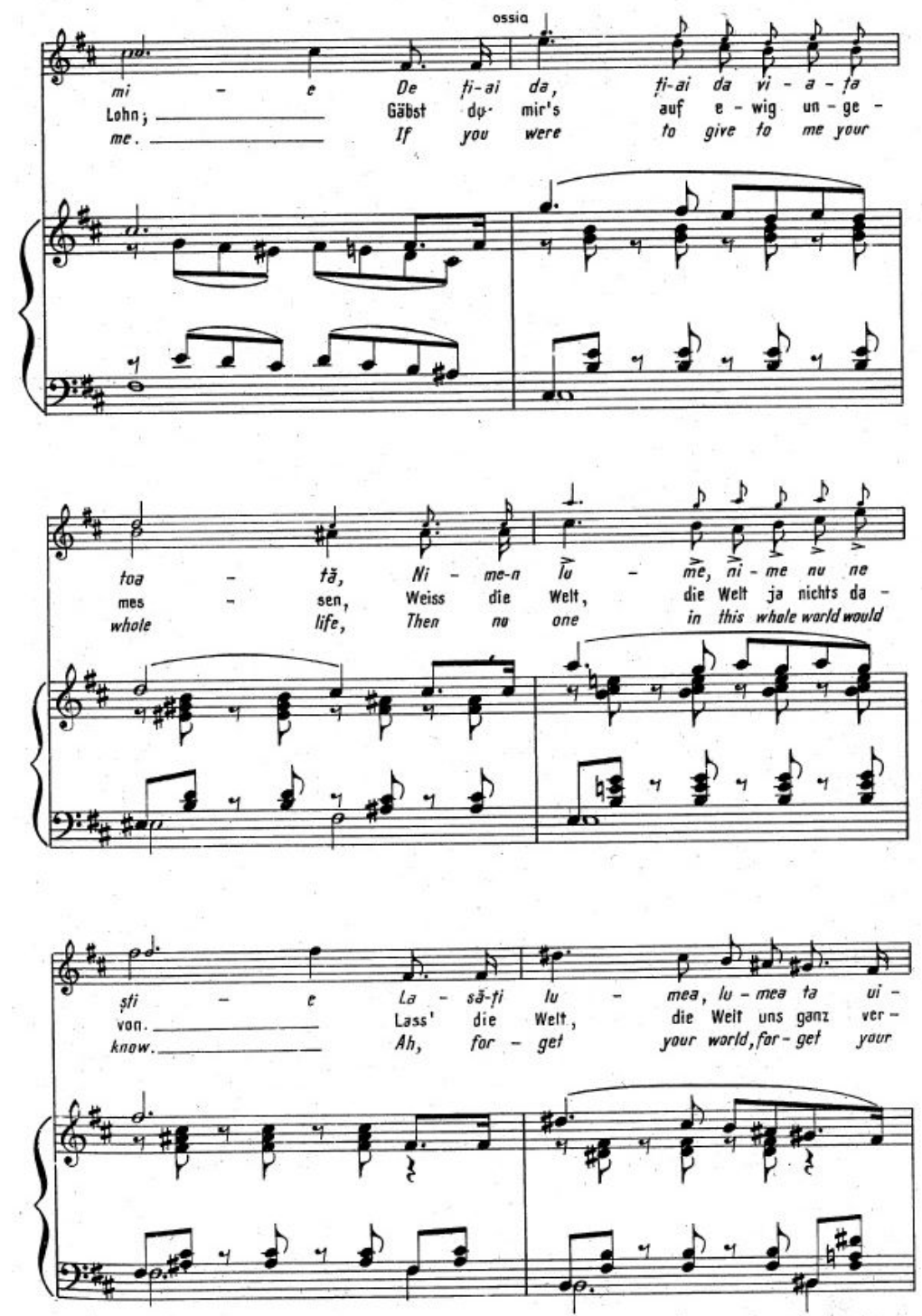

Fig. 2 Nicolae Bretan, Lasă-ți lumea ta uitată [Leave your World Forgotten], mm. 1-13

Another relevant source that reveals the inclination of musicologists ${ }^{18}$ to the comment on Nicolae Bretan's compositions is the magazine Muzica [Music] For example, in the article Opera română „Horia” de Nicolae Bretan [Horia, A Romanian Opera by Nicolae Bretan], which appeared in 1980, on the occasion

${ }^{18}$ Romeo Ghircoiașu, Viața și creația lui Nicolae Bretan [Life and Work of Nicolae Bretan], in: Muzica [Music Journal] no. 6, București, Editura Muzicală a Uniunii Compozitorilor din R.P.R., 1987, pp. 16-18; Viorel Cosma, Casiu Barbu, Concrete dedicate lui Nicolae Bretan [ Concerts dedicated to the creation of Nicolae Bretan], in: Muzica [Music Journal] no. 6, București, Editura Uniunii Compozitorilor R. S. R., 1987, pp. 19-20. 
of the premiere at the Opera Română [Romanian Opera] in Bucharest, Viorel Cosma noticed the 'simplicity of the music' (Cosma, 1980, p. 29) and the accessible character of the score by resorting to doina intonations or 'traditional romance' (Cosma, 1980, p. 29).

\section{Relationship amid promotion and reception during 1996-2013. Negative Consequences}

After the 1990s, the attention of Romanian interpreters or critics was drawn by the figure of the Swiss pianist Hartmut Gagelmann, whose involvement in the promotion of the composer recommended him as the ideal musician ${ }^{19}$. In order to develop an extensive research, Hartmut Gagelmann traveled to the United States, Hungary, Great Britain and Romania, engaging with with teachers, performers and directors, who collaborated directly or indirectly with the musician Nicolae Bretan, but especially with his daughter Judit. That was a favorable context for the author Hartmut Gagelmann, who completed in 1998 the first variation of the monograph research dedicated to the author: Nicolae Bretan seine Lieder, seine Oper, seine Leben ${ }^{20}$. It is surprising that Octavian Lazăr Cosma published a harsh review of this volume in the Muzica [Magazine Music] (Cosma, 1996, pp. 123-139) back in 1996, before the text appeared in Romanian. We can deduct that during the documentation stages, Gagelmann left the manuscript at the [Uniunea Compozitorilor și Muzicologilor] Union of Composers and Musicologists, giving to the researcher Octavian Lazăr Cosma the opportunity to read it. Once reading, the musicologist signaled the exaggerations made by the author (stylistic deformed classifications of Nicolae Bretan's compositional personality) and, moreover, the historical errors and controversies of musical-analytical nature, related to the comments on the vocal creation. For example, overtaken by the pathetic effusion of the controversial remarks on the stylistic cataloging of Nicolae Bretan and George Enescu, Gagelmann said: 'Bretan remained a Romanian composer, while Enescu became French according to the way he writes' (Cosma Lazăr, 1996, p. 226). It is shocking that, a few years later, the research

\footnotetext{
19 'As pianist répétiteur and conductor of the Municipal Theatre of Sankt Gallen, he was involved in the realization of the opera shows Golem, in the season 1990-1991. He was a jury member in the Nicolae Bretan Vocal Interpretation Competition in Cluj (1993-1994) and a specialized consultant for the staging of the operas Golem and Luceafärul [The Morning Star], interpreted by students of the Academy Gheorghe Dima of Cluj and soloists of the Opera Houses of Cluj and Bucharest, at the Franz Liszt Academy of Music of Budapest in 1993 and at the National Opera of Bucharest in 1995' (Gagelmann, 2005, p. 285).

${ }^{20}$ Nicolae Bretan Seine Lieder, seine Oper, seine Leben, Tipoholding, Verlag, Klausenberg, Cluj, 1998, 309 pages.
} 
in question was published first as a volume in English $^{21}$ and later on in Romanian $^{22}$.

The demonstrative publicity actions of the composer's music in America did not remain unanswered, concluding with the appearance of some writing, the pathetic content of which is simply surprising. For example, Irving Lowens, critic of the publication Washington Star and author of prestigious books ${ }^{23}$, concluded in 1983 the preface of the score Lieduri pe versurile poeților Heinrich Heine, Nikolaus Lenau, Reiner Maria Rilke [Lieders on the Verses of the Poets Heinrich Heine, Nikolaus Lenau and Reiner Maria Rilke ${ }^{24}$ with the following statement: 'If God had given me the talent and skill to compose lieder, I would wish to compose Bretan's lieder' (Lowens, 1983, p. XI).

It is obvious that the fabulous enterprise of promoting the musician at theoretical (recordings, articles, a monographic volume) or practical level (organizing recitals, author concerts, setting up performances in the country and abroad, publishing scores in prestigious publishing houses) would have never had the expected impact without the considerable financial support offered by Judit Bretan le Bovit. A peak moment was reached in 1994 when the well-known company Nimbus Records, was granted exclusivity rights for the distribution of Bretan's creation worldwide. Scenic creation, sacred music, and some lieder have been brought back to public attention since 1995. Nowadays, we would say that it is a gratifying decision, which would be worth applying to composers that are significant for the history of interwar Romanian music but did not have the chance to benefit from a similar advertising campaign. We would like to remind just the name of Mihail Jora, the creator of modern Romanian ballet and lied, who would really amaze foreign audiences due to his concrete innovations of language and sound expression.

In the Romanian specialized press, the perception of the musician remains within objective parameters, which can be proved through an extract from the chronicle Evenimentele muzicale ale miezului de stagiune [Musical Events of Middle Season] (2009) by Dumitru Avakian: 'At Bucharest Opera, Golem and Arald, two lyrical works in an act, signed by Nicolae Bretan from Cluj [...] have excelled in a striking simplism at compositional level, which could hardly be compensated at scenic level in the directorial vision of Anda Tăbăcaru“ (Avakian, 2009, p. 1).

\footnotetext{
${ }^{21}$ Hartmut Gagelmann, Nicolae Bretan: His Life His Music, editat de Nicolae Bretan Music Foundation, 2000, 309 pages.

${ }^{22}$ Nicolae Bretan: his Lieder - his Works - his Life/ Hartmut Gagelmann, translated by Petru Forna, revised by Pavel Puşcaş. Cluj-Napoca: Teognost Publishers, 2005.

${ }^{23}$ Irving Lowens (1916-1983), Lectures on the History and Art of Music (New York, 1968), Music in America and American Music: Two Views of the Scene, (Brooklyn, NY, 1978).

${ }^{24}$ Editio Musica, Budapest, 1983.
} 
The culminating point in the subjective reception of the musician is offered by Judit Bretan in the volume Uraganul. O viață pentru Nicolae Bretan. Mărturie in fragmente [Hurricane. A life for Nicolae Bretan. Testimony in fragments] (2013). Apart from the content of the letters she interprets in a speculative manner, the author launches the idea that the silence on the composer can be explained by the fact that he belongs to the dark period of the communist regime, as well as by his marriage to Nora Osvát, a Hungarian Jew, whose family was decimated in Auschwitz. The sensitive interethnic Hungarian-German-Jewish ties and the musician's resistance to integrating into the conspiracy of mediocrity of a dictatorship are the premises of a controversial discourse with pathetic nuances. For what purpose? The uninformed reader, visibly touched by the disturbing story, might conclude that Bretan was one of those important creators, who died unknown, unjustly blamed in postwar Romania, although he composed remarkable music. However, the careful lecturer shall certainly remark the lack of concrete documents that justify the idea that the personality of the artist was annihilated by the maneuvers of communist ideology. The natural questions are: What were the drastic decisions that the authorities adopted against him? What important scores were not interpreted? We should understand one more aspect: the pressure that Judit exerted in countless moments on the performers to interpret or record Bretan's music. For instance, we reproduce below a fragment that reveals the profoundly subjective reaction of the author, when conductor Cristian Mandeal refused to record a work in 1995. "The fees received by Mandeal at the Universities of Indiana and Rutgers - three thousand dollars, which were a fortune in Romania conditions, i.e. the earnings of a good conductor for many years, were transferred to my account, because he had no right as a Romanian citizen to hold a currency account abroad and we agreed to meet a few months later in Romania to record Horia... The recording never took place.” (Bretan, 2013, p. 323) Another idea that comes out of the volume is that Judit le Bovit, a professional actress with a remarkable literary culture, but not trained in music, was often in a position to manage the engagements of certain performers in Bretan's repertoire. Preoccupied to get categorical answers at all costs, regarding the organization of artistic events dedicated to her father's memory, and especially flattered by the laudatory remarks made by important names of the world of singing, she did not retaliate in exaggerated moments, which is unacceptable for a professional. "During a two-hour conversation that I had at the New York Metropolitan Museum on October 31, 2000, Angela Gheorghiu explained that Bretan was incomparably better and greater than Enescu... Enescu is inferior precisely in the most important point: concision. The proportion is: Bretan says in 4-5 minutes what Enescu says in 45 minutes" (Bretan, 2013, p. 367). 
From the provided examples, we noticed that the relationship between promotion and reception in the case of the composer Nicolae Bretan presented a differentiated fulfillment. Thus, in the first stage (1969-1995), we retain the objective views of some scholars, highlighting the importance of the creator in a balanced manner, with positive impact on his image and reputation. In the second stage (1997-2013), the demonstrative publication of volumes at national and international level, subjectively conceived, by the deliberate deformation of historical, stylistic and musical landmarks, led to negative consequences manifested in a distorted reception of its personality.

\section{Critical reception in the present. Conclusions}

From the systematized scrutiny of the bibliography that we construed in correlation with the particular observations regarding the musician's scores submitted to our attention, we found surprising that the silence on Bretan can be contextually perceived with the tense socio-political and family environment. The true reason for his partial recognition is related to the dubious quality of his performances, a fact that is related to genre creations in the nineteenth century and the cultivation of vocal miniature in the sense of romance and not of lied.

As for the genre of opera, we noticed obvious similarities of sonority, timbralism conception and drama character construction with German romantic composers: Carl Maria von Weber, Ferdinand von Hiller and Heinrich Marschner.

In his approach to romance, the composer takes over the modalities to construct melodies and the types of romantic accompaniment used by Franz Schubert and Felix Mendelssohn, which he simplifies, giving them a differentiated expressivity (delicate, lyrical, dramatic and pathetic). In that way, he follows the natural path of many Romanian creators that cultivated that genre, such as: Gheorghe Scheletti, Iacob Mureşianu, Gheorghe Dima and Tiberiu Brediceanu.

We have noticed that from a stylistic point of view, Nicolae Bretan cannot be put in the context of his generation, i.e. of the composers that have clearly contributed to the development of the genres under discussion. We are confronted with the phenomenon of epigonism ${ }^{25}$, which is a characteristic of minor creators that take over, without innovation, expression and language modalities from major composers belonging to a chronologically exhausted style. We consider that the affiliation to the 'minor' creator category does not undermine the value of Nicolae Bretan's personality, because the musician is currently perceived, especially through his contributions in the interpretative field.

\footnotetext{
${ }^{25}$ Epigon - name used for minor artists that mimic the means of expression specific to a great creator (https://dexonline.ro/definitie/epigon).
} 
In this sense, we noticed a gap in the manner of building the reception from a theoretical and practical perspective. Although the publication of articles in the press of that time and the comments in specialized journals led to the gradual recognition of the composer, in the interpretative plane, we should point out that the phenomenon of Bretan's rebirth was caused by the multitude of manifestations devoted to him.

Although the sonority of his vocal works is remarkable due to their obvious simplicity and not because of the deliberate simplicity of music, Bretan remains an artist appreciated by performers for the charm of his songs. The talented minor composer is a musician of high cultural value, whose simple creation has a clear effect on melomans and the capacity to stand the passage of time, beyond any exaggeration.

\section{References}

Avakian, D. (2009). Evenimentele muzicale ale miezului de stagiune [Musical Events of Middle Season]. România literară, 7, 1. Retreived from www. romlit. ro/index.pl/ evenimentele muzicale ale miezului de stagiune.

Brâncuși, P. (1969). Istoria muzicii românești [The History of Romanian Music]. București: Editura Muzicală a Uniunii Compozitorilor din R.S.R.

Bretan, J. (2013). Uraganul. O viață pentru Nicolae Bretan. Mărturie în fragmente [The Hurricane. A life for Nicolae Bretan. Testimony in Fragments]. Cluj-Napoca: Editura Casa Cărții de Știință.

Constantinescu, G. (1973). Nicolae Bretan. Contemporanul [The Contemporary], 16 (179), April 13, 6. București.

Cosma, V. (1980). Opera română: Horia de Nicolae Bretan [Romanian Opera: Horia by Nicolae Bretan]. Muzica [Music Journal], 9, 28-30. București: Editura Uniunii Compozitorilor din R.S.R.

Cosma, V. (1989). Nicolae Bretan. Muzicieni din România [Romanian Musicians], Lexicon, vol. 1 (AC), pp. 207-214. București: Editura Muzicală].

Cosma, O. L. (1983). Hronicul Muzicii Românești, V (1898-1920) [The Chronicle of Romanian Music], V. București: Editura Muzicală.

Cosma, O. L. (1995). Universul muzicii românești [The Universe of Romanian Music]. București: Editura Muzicală a Uniunii Compozitorilor și Muzicologilor din România.

Cosma. O. L. (1996). Ce se mai scrie despre Nicolae Bretan? [What is being written about Nicolae Bretan?]. Muzica [Music Journal], 2, 123-139. București: Editura Muzicală a Uniunii Compozitorilor şi Muzicologilor din România. 
Foucault, M. (1980). What is an Author? In Language, Counter - Memory, Practice, Selected Essays and Interviews (pp. 299-314). Ithaka, New-York: Cornell University Press.

Gagelmann, H. (2005). Nicolae Bretan Liedurile sale, operele lui viața sa, traducere de Petru Forna, revizuire de Petru Pavel Pușcaș [Nicolae Bretan, his Lieder and the Works of his Life, translation by Petru Forna, review by Pavel Puşcaş]. Cluj-Napoca: Editura Teognost .

Gherghel, I. (1936). Luceafărul lui Nicolae Bretan. [Nicolae Bretan's Morning Star]. Gazeta ilustrată [The Illustrated Gazette], 1-2, 6-7. Cluj: Tipografia Națională. Viața muzicală în Ardealul de după Unire [The musical life in Transylvania after the Great Union], Part I, Activitatea Operei Române din Cluj, în decurs de 16 stagiuni (19191935) [The Activity of the Romanian Opera of Cluj, during 16 seasons (1919-1935)] with an addition regarding the last four seasons (1935-1939). Cluj: Tipografia Națională.

Gherghel, I. (1939). Horia de Nicolae Bretan Horia by Nicolae Bretan. Gazeta ilustrată [The illustrated Gazette], 7-8, 102.

Hofmann, A. (1973). Concert Nicolae Bretan [A Concert by Nicolae Bretan]. România liberă [Free Romania], 31, 8858, April 17, 2. București.

Lowens, I. (1983). Nicolae Bretan, Lieders on the Verses of the Poets Heinrich Heine, Nikolaus Lenau and Reiner Maria Rilke. Budapest: Editio Musica.

Miletineanu, G. (1937). Horia de Nicolae Bretan [Horia by Nicolae Bretan]. Muzică și poezie [Music and poetry], anul II, 6, April, 30. București: Editura Fundațiilor Regale.

Ursu-Dragoş, V. (1937) Horia de Nicolae Bretan [Horia by Nicolae Bretan]. Muzică și poezie [Music and poetry]. anul II, 4, February, 32. București: Editura Fundațiilor Regale. 